\title{
Obituary for Engelbert Dockner
}

\author{
Josef Zechner ${ }^{1}$
}

Published online: 31 August 2017

(C) Wirtschaftsuniversität Wien, Austria 2017

On April 16th, Easter Sunday, 2017 Engelbert Dockner, one of the editors-in-chief of the Management Review Quarterly, passed away. His release from suffering brought on by an aggressive form of melanoma came peacefully in the presence of his family. He is survived by his loving wife Renate, his son Matthias and his daughter in law, Aileen.

Engelbert Dockner will be greatly missed, not only by his family and his friends, but also by the academic community. He will be missed as an insightful researcher, as an outstanding teacher and communicator, as an entrepreneur in both academia and financial practice, and, most sorely as a friend and a wonderful, unique person.

Born in the small community of Höbenbach in Lower Austria, Engelbert Dockner became an internationally renowned financial economist. His dissertation was in the field of mathematical economics. In his thesis he derived an expression that is crucial for the stability of dynamic optimization problems in the field of control theory. This expression is now commonly referred to as Dockner's " $\mathrm{K}$ ".

He obtained his Habilitation at the WU Vienna University of Economics and Business on "Dynamic Trade Policy and International Oligopolies" in 1993 and has published an impressive number of papers on various aspects of dynamic competition in oligopolistic markets. His research has also contributed significantly to the development of differential games. His book "Differential games in economics and management science", joint with Steffen Jörgensen, Ngo van Long and Gerhard Sorger, is by now a standard reference in this field.

Josef Zechner

josef.zechner@wu.ac.at

1 Department of Finance, Accounting and Statistics, Institute for Finance, Banking and Insurance, Wirtschaftsuniversität Wien, Vienna University of Economics and Business, Welthandelsplatz 1, 1020 Vienna, Austria 
He has held faculty positions at the University of Saskatchewan and Queen's University in Canada and at the University of Bielefeld before he returned to Vienna in 1993 as a Finance Professor at the University of Vienna. Since then, his research focused mostly on questions in finance, in particular at the intersection between corporate finance and asset pricing. In 2008 Engelbert Dockner joined the Institute of Finance Banking and Insurance at the WU Vienna University of Economics and Business. Most recently, his research analyzed the effect of imperfect competition on equity risk premia as well as on the risk-return factor structure of asset portfolios and the valuation of risky government bonds.

Engelbert Dockner was not only a successful researcher, but also a highly talented teacher and mentor. He has motivated generations of incoming finance students, patiently explaining to them the fundamental paradigms of modern finance. He has supervised a large number of master theses and dissertations. For many students, the fact the he has taken them under his wings, was the turning point towards a successful completion of their studies. His appreciating and encouraging feedback was continuing motivation not only for students, but also for his colleagues.

Engelbert Dockner's communication talent extended to his presentations for practitioners. Not only could he communicate in an intuitive and easily understandable way, but he was also able to clarify the practical relevance of theoretical concepts for practitioners. He clearly recognized the importance of communicating with the public and took the role of chairman of the advisory board of an important industry initiative to improve financial literacy, although he was already suffering from his illness. He was very much aware that a broad understanding of science is central in reducing the rising tensions between parts of the public and so-called experts.

Engelbert Dockner has provided substantial services to the academic community. Two activities were particularly important to him until the very end of his life. First, he was centrally involved in the establishment of the Vienna Graduate School of Finance, a joint Ph.D. program of the WU Vienna University of Economics and Business and the University of Vienna. It was his central objective to create an infrastructure to guide young academics to the scientific frontiers of the field. Graduates of the VGSF are now successful scholars and professors in many countries, including the USA, Australia, Germany, Hong Kong, Norway and the Arab Emirates. Not surprisingly, many of these graduates have sent touching condolence letters.

The second example of Engelbert Dockner's services to the academic community are his contributions as president of the European Finance Association, Europe's leading association of academics and practitioners in the field of finance. His successor, the current president of the Association, Arnoud Boot from the University of Amsterdam describes Engelbert Dockner's contributions to the EFA in the electronic condolence book: "Engelbert's boundless energy and selfless enthusiasm positively infused all EFA challenges he undertook, and his many excellent inspirational contributions have helped to reshape the EFA Annual Meeting into a conference of the highest echelon".

Despite his strong commitment to research, teaching, and service to the academic community, Engelbert Dockner has also contributed to the practical world of finance. He has co-founded several firms, including the asset management company "Institute for Quantitative Asset Management" which subsequently became "Spängler IQAM Invest". As a partner and member of the scientific board of this company, Engelbert 
Dockner has very much enjoyed his bridging function between the world of science and practical implementation.

Engelbert Dockner will be missed as a scientist, as a teacher an as an entrepreneurial spirit. But he will be missed particularly as a very special human being. His life has always reflected his values: deep empathy and appreciation for other people, optimism, intellectual openness and enlightenment. He was a true renaissance man. He has never put himself first, but because of his numerous contributions, he often ended up in the front line. His spirit of serving for a common goal instead of pursuing short-term selfinterest had enormously positive effects wherever he was. He will be dearly missed, not only by his family and good friends, but also by his colleagues and the scientific community at large. 